\title{
The war dead and their gravesites
}

\author{
Anna Petrig \\ Anna Petrig (LL.M. Harvard) is a former Attaché of the Legal Division of the \\ International Committee of the Red Cross and is currently working as a researcher \\ at the Max Planck Institute for Foreign and International Criminal Law in Freiburg, \\ Germany.
}

\begin{abstract}
International humanitarian law (IHL) contains various provisions pertaining to the dead in armed conflicts and their burial places. This article provides an overview of the various substantive obligations with regard to persons having lost their lives in armed conflicts and their gravesites. The temporal scope of application of these provisions namely whether they apply in times of peace-will also be analysed. Finally, the reasons why IHL as in force today is applicable to questions concerning the dead and their gravesites will be considered.
\end{abstract}

The respect and deference paid to the fallen in war can be seen throughout the world. In many cities, towns and villages the 'harsh history of life and death in wartime is frozen in public monuments' - be it in the form of a war memorial at a French railway station commemorating the railway workers who died in the First or Second World War, or a list of deceased Japanese soldiers displayed in a Gokoku shrine. Issues pertaining to persons who have lost their lives in war are highly sensitive and can easily cause public outrage. Thus the pictures of mutilated dead US soldiers dragged through the streets of Mogadishu in 1993 provoked consternation around the world and contributed to the withdrawal of the US troops from Somalia. ${ }^{2}$ More recently, the removal of a Red Army war memorial and a dozen graves in Tallinn led to massive protests which left one person dead and had a negative impact on the relationship between Estonia and Russia. ${ }^{3}$ Disputes over the maintenance of war cemeteries also regularly arise in all parts of the world - for example, the 2008 debate in Norway on whether the state remains under any 
international obligations with regard to deceased World War II combatants and their gravesites. ${ }^{4}$

Interests and humanitarian issues concerning the dead are many and varied. First and foremost, the personal dignity of the deceased must be safeguarded. In addition, the relatives' right to know the fate of their next of kin and their interest in recovering the dead or having access to the burial place must be ensured. Moreover, not only individuals but also states are stakeholders. Thus the home countries of soldiers buried on foreign soil generally have a keen interest in respect for and maintenance of their war graves. Finally, institutions mandated by the international community to investigate and prosecute crimes committed in armed conflict have an interest in obtaining evidence on the cause and circumstances of death.

Legal answers to questions concerning persons deceased in armed conflict and their gravesites are provided by various branches and sources of law, which are often cumulatively applicable. First, numerous bilateral or multilateral agreements between states - e.g. agreements on co-operation and mutual relations, peace treaties, ${ }^{5}$ or agreements exclusively dealing with war cemeteries ${ }^{6}-$ contain rules on the dead and their graves. Secondly, where such concrete rules are absent, fragmentary, non-binding or incompatible with international law, general norms of international humanitarian law and international human rights $\mathrm{law}^{7}$ can provide answers. Thirdly, international norms engaging individual criminal responsibility ${ }^{8}$ or state responsibility become relevant when primary norms laying down obligations towards the dead and their graves are violated. Fourthly, domestic law may be

1 Jay Winter, Sites of Memory, Sites of Mourning: The Great War in European Cultural History, Cambridge University Press, Cambridge, 1995, p. 78.

2 'Rebels drag soldiers' bodies through Mogadishu streets', The Guardian, 21 March 2007, available at: http://www.guardian.co.uk/world/2007/mar/21/1 (last visited 21 May 2009).

3 'Estonia to remove Soviet memorial', BBC News, 12 January 2007, available at: http://news.bbc.co.uk/2/ hi/europe/6255051.stm (last visited 21 May 2009); 'Estonia seals off Soviet memorial', BBC News, available at: http://news.bbc.co.uk/2/hi/europe/6597497.stm (last visited 21 May 2009).

4 Norwegian Parliament, written question from Ine Marie Søreide (H) to the Minister of Culture and Church Affairs (Stortinget, Skriftlig spørsmål fra Ine Marie Eriksen Søreide $(H)$ til kultur- og kirkeministeren), 16 June 2008, available at: http://www.stortinget.no/no/Saker-og-publikasjoner/Sporsmal/ Skriftlige-sporsmal-og-svar/Skriftlig-sporsmal/?qid=40641 (last visited 21 May 2009).

5 See e.g. Articles 225 and 226 of the Treaty of Versailles of 28 June 1919, available at: http://avalon. law.yale.edu/imt/partvi.asp (last visited 21 May 2009).

6 See e.g. the Exchange of Notes (With Annexes) between the Netherlands and the United States of America Constituting an Agreement Concerning the American War Cemetery at Margraten, The Hague, 26 September 1951, 158 UNTS 468; or Exchange of Notes between Austria and India Constituting an Agreement Concerning the Commonwealth War Cemetery at Klagenfurt, Vienna, 10 July 1968, 645 UNTS 65.

7 The following human rights contained in almost all regional and international human rights treaties are particularly relevant with regard to the dead and their graves: human dignity, freedom of religion, prohibition of cruel, inhuman or degrading treatment, respect for family and private life, and the right to privacy.

8 Article 8(2)(b)(xxi) and (c)(ii) of the Rome Statute prohibits the commission of outrages upon personal dignity in international and non-international armed conflicts. According to the Elements of Crimes, a dead person is a potential victim of this offence. See note 70 below. 
relevant, such as fundamental rights enshrined in constitutions or bills of rights, military law, public health law or criminal law.

This article focuses exclusively on the provisions pertaining to the dead and their gravesites that are contained in international humanitarian law. After providing an overview of the various substantive obligations and their temporal scope of application, namely whether they apply in times of peace, it will be discussed why IHL as in force today is applicable to questions concerning the deceased and their burial places.

\section{The dead and their gravesites: what substantive obligations does international humanitarian law contain?}

With regard to international armed conflicts, the four Geneva Conventions (GC I to IV $)^{9}$ and Additional Protocol I (AP I $)^{10}$ thereto contain various provisions specifically dealing with mortal remains and gravesites. The mesh of IHL provisions on the dead that are applicable in non-international armed conflicts is much less densely interwoven: the only provision explicitly mentioning the dead is Article 8 of Additional Protocol II (AP II). ${ }^{11}$ However, the absence of specific norms pertaining to the dead does not mean that the parties to the conflict can act in a legal vacuum. On the contrary, they are obliged to respect general norms of IHL, such as the prohibition of outrages upon personal dignity, in particular humiliating and degrading treatment; ${ }^{12}$ the prohibition of cruel and inhuman treatment; ${ }^{13}$ and the prohibition of collective punishment. ${ }^{14}$ In addition, customary international law ${ }^{15}$ on the dead might fill protection gaps in both types of conflicts. According to the ICRC Study on Customary International Humanitarian Law (ICRC study), all customary rules on the dead (with the exception of Rule 114 on the return

9 First Geneva Convention for the Amelioration of the Condition of the Wounded and Sick in Armed Forces in the Field, 12 August 1949, 75 UNTS 31 (hereinafter GC I); Second Geneva Convention for the Amelioration of the Condition of Wounded, Sick and Shipwrecked Members of Armed Forces at Sea, 12 August 1949, 75 UNTS 85(hereinafter GC II); Third Geneva Convention relative to the Treatment of Prisoners of War, 12 August 1949, 75 UNTS 135 (hereinafter GC III); Fourth Geneva Convention relative to the Protection of Civilian Persons in Time of War, 12 August 1949, 75 UNTS 287 (hereinafter GC IV).

10 Protocol Additional to the Geneva Conventions of 12 August 1949, and relating to the Protection of Victims of International Armed Conflicts, 8 June 1977, 1125 UNTS 3 (hereinafter AP I).

11 Protocol Additional to the Geneva Conventions of 12 August 1949, and relating to the Protection of Victims of Non-International Armed Conflicts, 8 June 1977, 1125 UNTS 609 (hereinafter AP II). Article 8 states that ' $\mathrm{w}]$ henever circumstances permit, and particularly after an engagement, all possible measures shall be taken, without delay [...] to search for the dead, prevent their being despoiled, and decently dispose of them'.

12 GC I-IV, Art. 3(1)(c), and AP II, Art. 4(2)(e).

13 GC I-IV, Art. 3(1), and AP II, Art. 4(1).

14 AP II, Art. 4(2)(b).

15 Reference will be made to the customary rules as identified in the ICRC study on customary international humanitarian law: Jean-Marie Henckaerts and Louise Doswald-Beck, Customary International Humanitarian Law, Volume I: Rules, Cambridge University Press, Geneva, 2006. 
of mortal remains and personal effects of the deceased) also apply to noninternational conflicts. ${ }^{16}$

\section{Terminology: the dead and their gravesites}

Different terms are used in IHL provisions on the dead to describe the person who died: 'the dead', ${ }^{17}$ 'dead person', ${ }^{18}$ 'bodies', ${ }^{19}$ 'the killed', ${ }^{20}$ 'the remains of deceased', ${ }^{21}$ or 'remains of persons who have died'. ${ }^{22}$ They should be understood as synonyms. Generally, the provisions on the dead and their graves equally apply to ashes. $^{23}$

While the term 'dead' is self-explanatory, a clear definition of the terms 'grave', ${ }^{24}$ 'gravesite', ${ }^{25}$ or 'other locations of the remains of persons ${ }^{26}$ is lacking. It is necessary to determine, for instance, whether the terms encompass monuments as such in memory of the dead, or mass graves resulting from the commission of crimes. The very wording of Article 34(2) of AP I - 'graves and, as the case may be, other locations of the remains of persons' - suggests a broad understanding of these notions. This view is supported by the respective commentaries on that article: "The fact that "other locations of the remains" of such persons are mentioned in addition to graves is in order to take into account all eventualities, lawful or unlawful, such as, in particular, cremation, collective graves, and even mass graves consequent upon atrocities committed during hostilities. ${ }^{27}$ Or: 'This broad terminology has been chosen in order to cover any form of disposal of the remains.

16 Ibid. The rules specifically dealing with mortal remains and gravesites are the following: - Rule 112 . Whenever circumstances permit, and particularly after an engagement, each party to the conflict must, without delay, take all possible measures to search for, collect and evacuate the dead without adverse distinction. [International and Non-International Armed Conflicts]-Rule 113. Each party to the conflict must take all possible measures to prevent the dead from being despoiled. Mutilation of dead bodies is prohibited. [International and Non-International Armed Conflicts]- Rule 114. Parties to the conflict must endeavour to facilitate the return of the remains of the deceased upon request of the party to which they belong or upon the request of their next of kin. They must return their personal effects to them. [International Armed Conflicts]- Rule 115. The dead must be disposed of in a respectful manner and their graves respected and properly maintained. [International and Non-International Armed Conflicts] - Rule 116. With a view to the identification of the dead, each party to the conflict must record all available information prior to disposal and mark the location of the graves. [International and Non-International Armed Conflicts].

17 GC I, Arts. 15(1) and 17; GC II, Arts. 18(1) and 20(1); AP II, Art. 8; Henckaerts and Doswald-Beck, above note 15 , Rules 112 to 116 .

18 GC I, Art. 16; GC II, Arts. 19 and 20(2).

19 GC I, Art. 17(3).

20 GC IV, Art. 15.

21 AP I, title of Art. 34.

22 AP I, Art. 34.

23 See e.g. GC I, Art. 17(3), and GC III, Art. 120(6).

24 See e.g. GC III, Art. 120(6), and GC IV, Art. 130(1).

25 See e.g. AP I, Art. 34.

26 AP I, Art. 34(2).

27 Yves Sandoz, Christophe Swinarski and Bruno Zimmermann (eds), Commentary on the Additional Protocols of 8 June 1977 to the Geneva Conventions of 12 August 1949, ICRC/Martinus Nijhoff, Geneva/ Dordrecht, 1987, p. 370, para. 1314. 
It covers cemeteries, any place where urns are stored, etc. ${ }^{28}$ Such an understanding seems justified, given the variety of religious and cultural practices to dispose of the dead. Furthermore, only an inclusive reading of the term 'gravesite' ensures that locations containing human remains other than sites established for commemoration, e.g. mass graves constructed in order to conceal the commission of crimes, ${ }^{29}$ are covered by IHL.

Even though a broad reading of the notion 'gravesite' seems justified, it needs to be determined whether sites not containing any mortal remains could qualify as a gravesite, such as the Cenotaph in Whitehall or the Monument to the Missing at Thiepval. ${ }^{30}$ The wording of various gravesite provisions implies that the site in question must contain mortal remains: 'graves together with particulars of the dead interred therein'31 or '[1]ists of graves and particulars of the prisoners of war interred in cemeteries and elsewhere', ${ }^{32}$ 'remains of deceased'33 or 'other locations of the remains of persons'. ${ }^{34}$ Hence monuments or memorials that are solely a remembrance without hosting any deceased cannot be subsumed under the term 'gravesite' as used in the treaty language. ${ }^{35}$ However, to qualify as such it should be sufficient that the gravesite contained some mortal remains at some point in time. ${ }^{36}$ Thus for instance, the obligation to maintain a cemetery should not terminate once the remains are completely decomposed, or when it is impossible to physically transfer all remains when a gravesite is relocated years after its creation. ${ }^{37}$

28 Michael Bothe, Karl Partsch and Waldemar Solf, New Rules for Victims of Armed Conflicts, Commentary on the Two 1977 Protocols Additional to the Geneva Conventions of 1949, Martinus Nijhoff, The Hague, 1982, p. 177.

29 That mass graves are covered by IHL provisions on the dead follows from Article 34(4) of Protocol I regulating exhumation in cases of investigative necessity; an obvious example of a gravesite that needs to be excavated for investigative purposes would be a mass grave.

30 The Cenotaph in Whitehall is an empty tomb in London that symbolizes the tomb of all those who died in the First World War; the Monument to the Missing at Thiepval in France displays on its internal walls the names of approximately 73,000 British and Allied men who died in the Battle of the Somme in 1916 and whose bodies were never found. See Winter, above note 1, pp. 102-105.

31 GC I, Art. 17(4).

32 GC III, Art. 120(6).

33 AP I, title of Art. 34

34 AP I, Art. 34(2).

35 However, if a memorial forms a unity with the grave - such as the statues by the German sculptor Käthe Kollwitz at the German war cemetery at Roggevelde where her son was buried (see Winter, above note 1, pp. 108-113) - the notion of 'gravesite' could be understood as encompassing the memorial. The American Battle Monuments Commission, which assumes the functions assigned by IHL to a Graves Registration Service, distinguishes between 'memorials' and 'cemeteries'. For a list of memorials, see http://www.abmc.gov/memorials/index.php (last visited 20 May 2009); for a list of permanent American burial grounds on foreign soil, see http://www.abmc.gov/cemeteries/cemeteries.php (last visited 20 May 2009).

36 Providing a definition that is neither overly inclusive nor too narrow is not simple in light of the variety of cultural and religious practices for disposing of the dead. The definition at hand excludes pure memorials; hence Shinto shrines - which do not host any dead bodies because they are perceived as impure and are therefore buried somewhere else - would for instance not be covered by the definition provided here.

37 E.g. the planned individual reburial of British and Australian troops found in a mass grave in France in 2008. See 'Australian, British WWI remains to be reburied', Agence France Presse, 1 August 2008, 


\section{Obligation to search for, collect, and evacuate the dead}

\section{Taking of all possible measures without adverse distinction}

Parties to conflict are under an obligation to search for the dead. ${ }^{38}$ Even though not explicitly stated in the respective treaty provisions - as it is in the customary rule $^{39}$ - the obligation must apply to all the dead 'without adverse distinction'. Not only is this an underlying principle of IHL, it is also affirmed with regard to the wounded and sick ${ }^{40}$ and can therefore be applied mutatis mutandis to the dead. Furthermore, the rules on the 'General protection of populations against certain consequences of war' in the Fourth Geneva Convention, to which the provision on the dead belongs, cover 'the whole of the populations of the countries in conflict, without any adverse distinction based, in particular, on race, nationality, religion or political opinion'. ${ }^{41}$ Under AP II, the general ratione personae provision also states that it 'shall be applied without any adverse distinction [...] to all persons affected by an armed conflict'. ${ }^{42}$

The search for the dead is a sine qua non for respect for other obligations pertaining to mortal remains and gravesites, such as returning the remains or providing a decent burial. ${ }^{43}$ Persons who die as a result of armed conflict often remain unaccounted for because their death is not recorded; the recording of information in turn is very difficult if the bodies or mortal remains of those killed in action or in extrajudicial killings are not collected. ${ }^{44}$ Thus for instance, the death of thousands of persons who died in concentration camps during the World War II, whose mortal remains were burned or otherwise disappeared, could only be established by assembling information found in the paper trail left by the Nazis, such as 'death books'..$^{45}$

available at: http://www.brisbanetimes.com.au/news/world/australian-british-wwi-remains-to-bereburied/2008/08/01/1217097470597.html (last visited 29 December 2008).

38 GC I, Art. 15; GC II, Art. 18(1); GC IV, Art. 16(2); AP II, Art. 8; Henckaerts and Doswald-Beck, above note 15 , Rule 112.

39 Henckaerts and Doswald-Beck, ibid., Rule 112.

40 GC I and II, Art. 12.

41 GC IV, Art. 13, read together with GC IV, Art. 16(2).

42 AP II, Art. 2(1).

43 Henckaerts and Doswald-Beck, above note 15, p. 407.

44 ICRC, Operational Best Practices Regarding the Management of Human Remains and Information on the Dead by Non-Specialists, For All Armed Forces, For All Humanitarian Organizations, p. 9, available at: http://www.icrc.org/Web/Eng/siteeng0.nsf/htmlall/p0858/\$File/ICRC_002_858.PDF!Open (last visited 20 May 2009).

45 The Nazis entered the names of interned persons who were murdered or perished in concentration camps in so-called 'Totenbüchern' ('death books'); however, these books do not account for every dead person, since many 'death books' were destroyed by the Nazis and no such books were kept in extermination camps where the newcomers from the transports were murdered on the spot. See http:// www.its-arolsen.org/en/help_and_faq/glossary/index.html (last visited 20 May 2009). For a list of other documents used by the International Tracing Service to trace missing persons and to ascertain the fate of victims of Nazi persecution, see http://www.its-arolsen.org/en/help_and_faq/dokumentenbeispiele/ index.html (last visited 20 May 2009). 
The First and Second Geneva Conventions, as well as customary law and Protocol II, oblige the parties to conflict 'to take all possible measures'. This wording indicates an obligation of means rather than result. The drafters were taking into account that in some cases collection of all the dead cannot be achieved - for instance because ongoing military operations make it impossible for medical personnel to search for and collect the dead (especially if priority must be given to the wounded), ${ }^{46}$ or if in naval warfare a rescue operation would expose the vessel to attack. ${ }^{47}$ The measures sufficient to meet this obligation can vary: in naval warfare, for instance, certain fighting ships such as fast torpedo-boats or submarines will have inadequate equipment or insufficient accommodation to pick up the crews of ships they have sunk. In these cases, the obligation can be met by alerting hospital ships or coastal authorities, requesting assistance from air forces or appealing to neutral vessels. ${ }^{48}$

\section{Time and circumstances}

The various provisions differ with regard to when and under which circumstances rescue operations must take place. GC I requires that they be carried out not only after an engagement - as was stated in the 1929 Geneva Convention - but 'at all times'. This broader time element was introduced in 1949 to take into account the realities of contemporary warfare in which hostilities became more continuous in character, compared with the past. ${ }^{49}$ However, with regard to naval warfare the drafters were of the view that the term 'after each engagement' was better suited to the special conditions prevailing at sea than the wording 'at all times' ${ }^{50}$ The provision in the Fourth Geneva Convention commands that the dead be searched for only '[a]s far as military considerations allow'. ${ }^{51}$

So while GC I and GC II emphasize the humanity principle, GC IV places the emphasis on military necessity. However, according to the ICRC Commentary, the 'difference is more apparent than real', and the extent of the obligation under GC IV would be similar to that under GC I and GC II - the different wording would only have been chosen because under GC IV, 'the service responsible for searching for wounded and dead is placed not under the control of military commanders, but under that of the civilian authorities; it is obvious that the latter could not send relief teams into the battle area without taking into account the

46 See GC I, Art. 12(3), stating that only urgent medical reasons authorize priority in the order of treatment to be administered.

47 Jean Pictet (ed), The Geneva Conventions of 12 August 1949: Commentary, Vol. I (Geneva Convention for the Amelioration of the Condition of the Wounded and Sick in Armed Forces in the Field), Art. 15, p. 151; Vol. II (Geneva Convention for the Amelioration of the Condition of Wounded, Sick and Shipwrecked Members of Armed Forces at Sea), Art. 18, p. 131.

48 GC II, Art. 21(1); Pictet, above note 47, Vol. II, Art. 18, p. 131.

49 GC I, Art. 15; Pictet, ibid., Vol. I, Art. 15, p. 151.

50 GC II, Art. 18; Pictet, ibid., Vol. II, Art. 18, p. 132.

51 GC IV, Art. 16(2). 
essential military requirements. Consequently, the Diplomatic Conference rejected various proposals that the reservation should be omitted. ${ }^{52}$

The wording 'at all times' used in GC I might be misleading, as the obligation to search is not absolute but hinges on the realities on the battlefield. On the other hand, the formulation '[a]s far as military considerations allow' used in GC IV could imply that considerations of humanity should not be given weight when deciding upon a rescue operation. Thus the wording in Article 8 of AP II and the customary norm ${ }^{53}-$ ' $[\mathrm{w}]$ henever circumstances permit, and particularly after an engagement' - might best reflect the current understanding of when and under which circumstances the obligation to search, collect and evacuate has to be carried out, whether in international or non-international armed conflict.

\section{The addressees of the obligation to search for, collect and evacuate the dead}

In international armed conflicts, the obligation to search for the dead is addressed to the parties to the conflict. The ICRC Commentary on the First Geneva Convention reflects a traditional concept of warfare when stating that 'the commonest and the most important case will be that of enemy troops retiring in the face of an attack. The occupant of the battlefield must then, without delay, make a thorough search of the captured ground so as to pick up all the victims' ${ }^{54}$ However, in times of remote warfare, the search for and collection of the dead might no longer be carried out first and foremost by the enemy troops, who are then not physically present on the battlefield.

In non-international armed conflicts, Article 3 common to the four Geneva Conventions implies that not only the ratifying (state) party, but every party to a non-international armed conflict, is required to apply its guarantees 'by the mere fact of that Party's existence and the existence of an armed conflict between it and the other Party'. ${ }^{55}$ AP II likewise imposes the same duties on both state and insurgent parties to the conflict. ${ }^{56}$ Thus it follows that non-state parties to a conflict are also bound by the obligation to search for, collect and evacuate the dead. However, to successfully discharge certain obligations, a certain degree of control over the territory might be necessary, meaning that all parties to the conflict might not be able to perform every obligation to the same extent at all times.

53 Henckaerts and Doswald-Beck, above note 15, Rule 112.

54 Pictet, above note 47, Vol. I, Art. 15, p. 151.

55 Ibid., Vol. I, Art. 3, p. 51.

56 Sandoz, Swinarski and Zimmermann (eds), above note 27, p. 1345, para. 4442. 


\section{Appeal to the civilian population and aid societies}

Parties to conflict may appeal to - but have no right to 'mobilize ${ }^{57}$ - the civilian population and aid societies to search for the dead and report their location. ${ }^{58}$ The drafters' intention in Article 17 of AP I was to limit the task of the civilian population and aid societies to searching for the dead and reporting their location, and to exclude the collection of the dead by them..$^{59}$ However, the functions of the teams mentioned in Article 33(4) thereof - which can consist of personnel of international humanitarian organizations $s^{60}$ - include the collection of the dead. This contradiction between the two provisions of AP I (or rather their interpretations by commentators) does not seem to stand in the way of humanitarian organizations assisting parties to conflict in the collection of the dead. The ICRC and National Societies, for instance, not only engage in searching for and reporting the location of the dead, but also in the collection of mortal remains. ${ }^{61}$

The law of non-international armed conflicts does not specify how to carry out the search for and collection of the dead, ${ }^{62}$ but as relief societies and the civilian population may offer their services for the collection and care of the wounded, sick and shipwrecked, ${ }^{63}$ they should by analogy also be able to do so with regard to the dead.

\section{Persons covered by the obligation to search for, collect and evacuate the dead}

It is submitted that 'the dead' covered by the GC I and GC $\mathrm{II}^{64}$ provisions on the search, collection and evacuation of the dead include protected persons covered by general ratione personae provisions, ${ }^{65}$ as well as a party's own nationals, even though the latter are generally not beneficiaries of the Geneva Conventions. ${ }^{66}$ First, the simple reference to 'the dead' can be contrasted with provisions on identification of the dead using the words 'dead person of the adverse Party'. ${ }^{67}$ The ICRC Commentary confirms (with regard to GC I) that Article 15 'deals with soldiers

57 Pictet, above note 47, Vol. I, Art. 17, p. 218.

58 AP I, Art. 17(2); provision for the civilian population (without mentioning relief societies) to assume such a role is made in GC I, Art. 18, only with regard to the wounded and sick; GC II, Art. 21(1), states that the parties to the conflict may appeal to the charity of commanders of neutral vessels to collect the dead.

59 Sandoz, Swinarski and Zimmermann (eds), above note 27, Art. 17, p. 218, para. 724.

60 Ibid., Art. 33, p. 363, para. 1289.

61 Annual Report 2008, ICRC, Geneva, 2008, p. 187 (on ICRC activities in Afghanistan pertaining to the collection, burial and/or repatriation of human remains after fighting) and p. 350 (on ICRC help for the Palestine Red Crescent and Ministry of Health emergency services in the collection of dead bodies).

62 See AP II, Art. 8.

63 AP II, Art. 18(1).

64 GC I Art. 15(1); GC II, Art. 18.

65 GC I and II, Art 13. Similarly to GC I, Art. 13 of GC II defining the passive personal scope of application does not mention the dead, but simply the wounded, sick and shipwrecked at sea.

66 Pictet, above note 52, Vol. IV, Art. 4, p. 46.

67 GC I, Art. 16(1) (emphasis added); GC II, Art. 19 (emphasis added). 
who have fallen wounded or sick in the actual area where fighting takes place, and defines the obligations incumbent on both friend and foe in regard to them', while on the other hand, Article 16 deals with obligations towards the wounded and sick of the opposing party once they have been collected. ${ }^{68}$ Secondly, the corresponding obligation in GC IV applies to the whole civilian population - whether foreign or own nationals in the territories of the parties to the conflict. ${ }^{69}$ It would consequently be difficult to argue that a state's own civilian nationals are covered in GC IV, but not its own combatants in GC I. Thus the obligation to search for the dead and prevent their being despoiled applies similarly to both enemy and own nationals.

In the law of non-international armed conflicts, Common Article 3 of the Geneva Conventions does not explicitly list the dead among the persons covered by its guarantees. However, the obligation to treat humanely all '[p] ersons taking no active part in the hostilities, including [...] those placed hors de combat by [...] any other cause' than sickness, wounds, or detention, could arguably apply to deceased persons. ${ }^{70}$ Relatives of the deceased falling within the personal scope of application of Common Article 3 could also invoke its guarantees, for instance by claiming that non-respect for their relative's mortal remains constitutes inhuman treatment or, more specifically, an outrage upon their dignity. ${ }^{71}$ The obligations in Protocol II regarding the dead are for the benefit of 'all persons affected by an armed conflict', ${ }^{72}$ regardless of their location, as according to the ICRC Commentary, '[p]ersons affected by the conflict $[. .$.$] are covered by the Protocol wherever they are in the$ territory of the State engaged in conflict. ${ }^{73}$

\section{Respect for the dead}

The command that mortal remains must be respected ${ }^{74}$ is a concretization of the general obligation to protect the dignity of persons and the prohibition of outrages upon personal dignity. Such outrages can constitute an offence under the Rome Statute; ${ }^{75}$ the respective Elements of Crimes specify that the victim need not

68 Pictet, above note 47, Vol. I, Art. 16, p. 159 (emphasis added).

69 GC IV, Art. 16 (obligation to search for the killed and to protect them against pillage and ill-treatment), read together with GC IV, Art. 13 (in which the definition of the persons covered by GC IV, Arts. 14 to 26, differs from that of GC IV, Art. 4).

70 The Assembly of States Parties to the ICC Statute considers that for purposes of the Statute, a dead person could potentially be a victim of the crime of committing outrages upon the personal dignity. See International Criminal Court, Elements of Crimes, adopted by the Assembly of States Parties, First Session, New York, 3-10 September 2002, Official Records ICC-ASP/1/3, Art. 8(2)(b)(xxi), fn. 49, and Art. 8(2)(c)(ii), fn. 57: 'For this crime, "persons" can include dead persons. It is understood that the victim need not personally be aware of the existence of the humiliation or degradation or other violation'.

71 For a practical example, see the text accompanying note 105 below.

72 AP II, Art. 2(1).

73 Sandoz, Swinarski and Zimmermann (eds), above note 27, Art. 2, pp. 1359-1360, para. 4490.

74 See e.g. AP I, Art. 34(1).

75 Rome Statute, Art. 8(2)(b)(xxi) and Art. 8(2)(c)(ii). 
personally be aware of the existence of the offence and that the term 'person' used in the criminal provision includes the dead. ${ }^{76}$

The general notion of respect includes preventing the dead from being despoiled. ${ }^{77}$ This concretization of the general prohibition of pillage is intended to guard the dead from those who may seek to lay hands on them and to prevent them from falling prey to the 'hyenas of the battlefield'. The US Military Tribunal at Nuremberg stated, in the Pohl case, that robbing the dead 'is and always has been a crime' ${ }^{78}$ While this pronouncement relates to the belongings of the dead, the prohibition of ill-treatment and mutilation ${ }^{79}$ protects the mortal remains as such. Trials held in the aftermath of the Second World War revealed odious acts of mutilation of dead bodies, ${ }^{80}$ as well as cannibalism. ${ }^{81}$ Respect further requires that dead bodies not be exposed to public curiosity and that this be avoided by placing them in an appropriate place before burial or cremation. ${ }^{82}$

\section{Identification and recording of information on the dead}

'History counts its skeletons in round numbers. A thousand and one remain a thousand as though the one never existed. ${ }^{83}$ While accounting for every dead person might not be necessary in order to establish a reliable historical record, it is of major importance when seen through the eyes of surviving dependants. Often only the official establishment of death can close the circle of uncertainty and put an end to relatives' false hopes. In this way acknowledgment of the loss of life represents a first step in the mourning process. Being in possession of information about the fate of relatives not only has a psychological and emotional component, but is also of great legal significance: many rights of the survivors only take effect once death is established, for instance by the issuing of a death certificate. This in turn necessitates that human remains are identified and information is recorded and transferred to the respective authorities. Moreover, proper identification and

76 See International Criminal Court, above note 70.

77 GC I, Art.15; GC II, Art. 18(1); GC IV, Art. 16(2); AP II, Art. 8; Henckaerts and Doswald-Beck, above note 15 , Rule 113.

78 US Military Tribunal at Nuremberg, Pohl Case, Judgment, 3 November 1947, reproduced in Henckaerts and Doswald-Beck, above note 15, p. 409.

79 GC IV, Art. 16(1); Henckaerts and Doswald-Beck, above note 15, Rule 113.

80 In 1946 the US Military Commission at Yokohama sentenced Japanese soldiers for 'bayoneting and mutilating the dead body of a United States prisoner of war' (Kikuchi and Mahuchi Case, Judgment of 20 April 1946). In 1947 the US General Military Court at Dachau found a German medical officer guilty of maltreating the body of a deceased US airman. The convicted officer had severed the head from the dead man's body, had baked it, removed the skin and flesh and bleached the skull (Schmid Case, Judgment of 19 May 1947). The cases are reproduced in Henckaerts and Doswald-Beck, above note 15, p. 409.

81 In 1946 the US Military Commission in the Mariana Islands convicted soldiers for 'preventing an honorable burial due to the consumption of parts of the bodies of prisoners of war by the accused during a special meal in the officers' mess' (Yochio and Others Case, Judgment 2-15 August 1946); reproduced in Henckaerts and Doswald-Beck, above note 15, p. 409.

82 Sandoz, Swinarski and Zimmermann (eds), above note 27, Art. 34, p. 369, para. 1307.

83 Wislawa Szymborska, 'Hunger camp at Jasko', in Carolyn Forche (ed), Against Forgetting: Twentieth Century Poetry of Witness, W.W. Norton, New York, 1993, p. 459. 
recording of information on the dead is also a means of fulfilling the right of human beings not to lose their identity after death. ${ }^{84}$

All four Geneva Conventions require an examination of the body, preferably carried out by a physician, with a view to confirming death and establishing identity. ${ }^{85}$ In addition, GC I and GC II oblige parties to the conflict to record as soon as possible any other information which may assist in the identification of the dead collected on the battlefield and provides an indicative list of particulars to be registered. ${ }^{86}$ The Third and Fourth Geneva Conventions (GC III and GC IV), both dealing with persons in the hands of the enemy, oblige the detaining power to issue death certificates or certified lists containing, inter alia, information about the deceased person and the circumstances of death. ${ }^{87}$ All four treaties provide for channels through which this information should pass from the enemy power to the respective addressee. ${ }^{88}$ The injunction to collect, record and transmit information about the dead is intended to ensure that the person does not remain unaccounted for, and that the right of families to know the fate of their relatives ${ }^{89}$ can be respected.

The wording 'Parties to the conflict shall ensure...' used in the respective provisions constitutes an obligation; hence they must 'make certain that the prescribed task, for which they are responsible, is duly carried out. There is no justification for thinking that the task is optional'.$^{90}$ However, the obligation should be regarded as fulfilled as long as parties make every possible effort and use all means at their disposal to do so - even if this fails to result in an identification of the person. Thus other interests, such as public health concerns making swift burials imperative and not allowing for identification of all persons (as was the case in Chad in 2008), ${ }^{91}$ may be taken into account. Some identification measures are already foreseen in the Geneva Conventions, such as collecting half of the identity disk or conducting autopsies. ${ }^{92}$ Depending on the context and the warring parties, more elaborate means such as DNA samples may be used. ${ }^{93}$

84 Interpol, ICPO-Interpol General Assembly, 65th session, Resolution AGN/65/RES/13 (1996), available at: http://www.interpol.int/Public/ICPO/GeneralAssembly/Agn65/Resolutions/AGN65RES13.asp (last visited 21 May 2009).

85 GC I, Art. 17(1); GC II, Art. 20(1); GC III, Art. 120(3); GC IV, Art. 129(2). No similar provision exists for non-international armed conflict; the obligations have however been consolidated in customary law. See Henckaerts and Doswald-Beck, above note 15, Rule 116.

86 GC I, Art. 16, and GC II, Art. 19(1).

87 GC III, Art. 120(2), and GC IV, Art. 129.

88 GC I, Art. 16(2) and (3); GC II, Art. 19(2) and (3); GC III, Art. 120(1) and (2); GC IV, Art. 129(1) and (3).

89 AP I, Art. 32.

90 Pictet, above note 47, Vol. I, Art. 16, pp. 176-177.

91 See e.g. ICRC, Chad: Saving lives as fighting subsides, Operational Update, 7 February 2008, available at: http://icrc.org/web/eng/siteeng0.nsf/html/chad-update-070208 (last visited 30 March 2009).

92 Henckaerts and Doswald-Beck, above note 15, pp. 419-420.

93 Luc Capdevila and Danièle Voldman, 'Du numéro matricule au code génétique: la manipulation du corps des tués de la guerre en quête d'identité', International Review of the Red Cross, Vol. 84, No. 848, December 2002, pp. 751-765. 


\section{Return of mortal remains and personal effects of the dead}

\section{Mortal remains}

GC I and GC II provide for the possibility of transferring bodies to the home country. ${ }^{94}$ During the drafting of the Geneva Conventions some delegations wished to omit this reference altogether, since they preferred to have their combatants buried in the actual theatre of war where they fell. Others pleaded for an imperative clause to bring the dead home at the close of the hostilities. To strike a balance between these diverging views on where fallen soldiers should be laid to rest, the clause was left optional. In GC III and GC IV, only the possibility of returning ashes is explicitly stated. ${ }^{95}$

For the High Contracting Parties to AP I in whose territory graves or mortal remains are situated, it is mandatory to conclude agreements in order to facilitate the repatriation of mortal remains. ${ }^{96} \mathrm{~A}$ request for the return of mortal remains can be formulated either by the home country or by the next of kin. However, the home country can object to a request by relatives. This veto power of the home country was deemed essential to the maintenance of war cemeteries in foreign countries. In particular, countries belonging to the British Commonwealth followed a policy of interring their soldiers in quite large war cemeteries in the country where they fell - for example, the Tyne Cot cemetery in Belgium hosting fallen soldiers from the Great War. ${ }^{97}$ If families had an unlimited right to request exhumation and repatriation, the integrity of these cemeteries could not be ensured..$^{98}$

The return of mortal remains often takes place years after the end of hostilities, such as Indonesia's 1991 handover of the ashes of 3500 Japanese soldiers killed during the Second World War to the Japanese ambassador in Jakarta. ${ }^{99}$ It is not uncommon for the ICRC to act as a neutral intermediary between warring parties for this purpose; to give only one example, it facilitated the handover of deceased persons between the Israeli authorities and Hezbollah in July 2008. ${ }^{100}$

In non-international armed conflicts, neither a treaty nor a customary rule explicitly covers the return of mortal remains. This is a real gap in humanitarian law. The ICRC Study merely recognizes a trend towards an obligation for the parties to such conflicts to return the mortal remains and effects of the deceased. ${ }^{101}$ Only by recourse to general norms of IHL can an obligation to return the mortal

94 GC I, Art. 17(3), and Art. 20(2) of GC II referring to the provisions on the dead contained in GC I.

95 GC III, Art. 120(6), and GC IV, Art. 130(2).

96 AP I, Art. 34(2).

97 The Commonwealth War Graves Commission provides a description of this war cemetery. See http:// www.cwgc.org/search/cemetery_details.aspx? cemetery=85900\&mode=1 (last visited 21 May 2009).

98 Bothe, Partsch and Solf, above note 28, p. 179.

99 Henckaerts and Doswald-Beck, above note 15, p. 412.

100 'Hezbollah, Israel swap corpses on Lebanon border', Reuters, 16 July 2008, available at: http:// www.reuters.com/article/homepageCrisis/idUSL16516924._CH_.2400 (last visited 21 May 2009).

101 Henckaerts and Doswald-Beck, above note 15, pp. 411-412. 
remains be construed. It could accordingly be argued that not returning mortal remains to the relatives constitutes a form of collective punishment ${ }^{102}$ and violates the prohibition of cruel or inhuman treatment ${ }^{103}$ and of outrages upon personal dignity, in particular humiliating and degrading treatment. ${ }^{104}$ In Russia, for instance, a federal law forbids authorities to return the bodies of persons qualified as terrorists to their families or to inform the relatives about their place of burial. Thus the bodies of several people killed in Chechnya, who were qualified as terrorists, were not handed over to their families for burial despite pleas and persistent efforts. Russia's Constitutional Court upheld the ban on handing over bodies of persons classed as terrorists and turned down several appeals filed by relatives of the deceased. ${ }^{105}$ It could be argued that this legislation and practice violate the prohibition of collective punishment since relatives - who did not themselves commit hostile acts - suffer some form of punishment if deprived of the possibility to perform funeral rites. Furthermore, the anguish caused by the lasting uncertainty as to the whereabouts of the remains and their actual treatment could constitute psychological suffering and feelings of degradation that might reach the level of inhuman treatment or qualify as an outrage upon personal dignity.

\section{Personal effects}

The parties to an international armed conflict are under an obligation to forward personal effects of deceased protected persons through the information bureau provided for in GC III ${ }^{106}$ to their country of origin. ${ }^{107}$ The terms 'personal effects' or 'personal valuables' have to be understood in a broad sense as including last wills, other documents of importance to the next of kin, money, and also articles of an intrinsic or sentimental value. However, weapons and other military material may be kept as war booty. ${ }^{108}$

\section{Disposal of the body}

Notwithstanding how a conflict is qualified, the parties must dispose of the dead respectfully. However, only the law of international armed conflict specifies what is meant by this, specifically requiring, inter alia, individual burial according to the

102 AP II, Art. 4(2)(b).

103 GC I-IV, Art. 3(1), and AP II, Art. 4(1).

104 GC I-IV, Art. 3(1)(c), and AP II, Art. 4(2)(e).

105 'Court upholds ban on returning terrorists' bodies to relatives', RIA Novosti, 28 June 2008, available at: http://en.rian.ru/russia/20070628/67977135.html (last visited 21 May 2009); Sudha Ramachandran, 'The dreadful dead of terror', Asia Times Online, 7 July 2004, available at: http://www.atimes.com/atimes/ South_Asia/FG07Df05.html (last visited 21 May 2009).

106 GC III, Art. 122.

107 GC I, Art. 16(3); GC II, Art. 19(3), GC III; Art. 122(9); GC IV, Art. 139. With regard to non-international armed conflicts, no specific obligation exists.

108 Henckaerts and Doswald-Beck, above note 15, p. 413. 
deceased's religious beliefs, and the grouping of graves. The interpretative text in the ICRC Study expresses some hesitation as to whether such precise guarantees exist under the law of non-international armed conflicts, merely stating that: 'It is likely that some of these requirements also apply in non-international armed conflicts on the basis of national law'. ${ }^{109}$

\section{Respect for the body and for religious beliefs}

The four Geneva Conventions prescribe that the dead must be honourably interred and that the rites of the religion to which the deceased belonged must - if possible - be respected. ${ }^{110}$ Given that some rites, such as those requiring the use of special ingredients or the sacrifice of an animal, might be difficult to observe in the special context of armed conflict where the death toll is usually high and resources scarce, an optional rather than a mandatory clause was enacted. ${ }^{11}$

\section{Individual burial and grouping of graves}

The Geneva Conventions furthermore mandate the warring parties to bury the deceased - as far as circumstances permit - individually and not in collective graves. ${ }^{112}$ The rationale behind these provisions is that the idea of common graves conflicts with the sentiment of respect for the dead and would also make subsequent exhumation more difficult. ${ }^{113}$ However, these interests might be overridden, for instance by public health concerns or military considerations. ${ }^{114}$

According to the Geneva Conventions, graves have to be grouped, if possible, according to the nationality of the deceased. ${ }^{115}$ The drafters' intention was to avoid hasty roadside burials and to achieve the grouping of graves in cemeteries. Besides nationality being the most obvious criterion for the grouping, it also allows the home country to pay collective tribute to its dead at a later date. ${ }^{116}$

\section{Burial favoured over cremation}

The provisions on the dead contained in the four Geneva Conventions strongly favour burial over cremation. Bodies can only be cremated for imperative reasons of hygiene or for motives based on the religion of the deceased. ${ }^{117}$ GC III and GC IV allow for cremation if this was the wish of the deceased prisoner of war or

109 Ibid., p. 417.

110 GC I, Art. 17(3); GC III, Art. 120(4); GC IV, Art. 130(1).

111 Pictet, above note 47, Vol. I, Art. 17, p. 179; Jean Pictet (ed), The Geneva Conventions of 12 August 1949: Commentary, Vol. III, Geneva Convention Relative to the Treatment of Prisoners of War, Art. 120, p. 565.

112 GC I, Art. 17(1); GC II, Art. 20(1); GC III, Art. 120(5); GC IV, Art. 130(2).

113 Pictet, above note 47, Vol. I, Art. 17, p. 177.

114 Pictet, above note 52, Vol. IV, Art. 120, p. 507.

115 GC I, Art. 17(3), and GC III, Art. 120(4).

116 Pictet, above note 47, Vol. I, Art. 17, p. 180.

117 GC I, Art. 17(2); GC III, Art. 120(5); GC IV, Art. 130(2). 
internee. ${ }^{118}$ The idea of a general prohibition on cremation was new when the 1949 Conventions were drafted and partly stemmed from a fear of repetition of certain criminal acts that occurred during the Second World War. ${ }^{119}$ The Conventions further require that if cremation is exceptionally allowed, the reasons for doing so should be stated in the death certificate or the authenticated lists of the dead. ${ }^{120}$ This requirement helps to avoid all traces of the deceased being eradicated and the dead thus remaining unaccounted for.

\section{Persons covered by obligations regarding human remains}

Articles 16 and 17 of GC I both only apply to the dead of the adverse party. Although only the former provision specifies this, whereas the latter simply uses the term 'the dead', the conclusion that the persons covered by Article 17 are dead persons of the adverse party is supported by its reference to 'the home country' ${ }^{121}$ This scope of application is mirrored by the corresponding provisions in GC II on recording and forwarding information on the dead ${ }^{122}$ and on what should happen with their bodies. ${ }^{123}$ The provisions of GC III under the heading 'Death of prisoners of war' ${ }^{124}$, however, cite persons who died while prisoners of war as the persons to whom they apply. ${ }^{125} \mathrm{GC}$ IV's provisions on the dead ${ }^{126}$ apply only to 'internees who died while interned' or 'deceased internees', i.e. protected persons ${ }^{127}$ who were interned on the basis of Articles 41 to 43, 68, or 79 of GC IV.

In general, it can be said that the provisions on the dead contained in each of the Geneva Conventions (including those on gravesites, discussed below) apply only to a limited circle of deceased persons. ${ }^{128}$ Protocol I aimed to fill these

118 GC III, Art. 120(5), and GC IV, Art. 130(2). GC I and GC II do not contain this further justification for cremation since they are essentially concerned with the dead picked up on the battlefield, where such a wish would be difficult to ascertain.

119 Pictet, above note 47, Vol. I, Art. 17, pp. 178-179.

120 GC I, Art. 17(2); GC II, Art. 20(2); GC III, Art. 120(5); GC IV, Art. 130(2).

121 AP I, Art. 34, also contains similar guarantees to GC I, Arts. 16 and 17, and is - according to the travaux préparatoires - not applicable to a state's own nationals; see note 133 below. It should also be recalled that under the 1929 Geneva Convention, the obligations in GC I, Arts. 16 and 17, were contained in one single article and were only divided in 1949 when they were spelled out in much more detail. See Pictet, above note 47, Vol. I, Art. 17, pp. 175-176.

122 GC II, Art. 19.

123 GC II, Art. 20. With regard to disposal of the body, it should be noted that if the dead person is taken ashore, that person then comes within the ambit of GC I (GC II, Art. 20(2)).

124 GC III, Arts. 120-121.

125 For an overview on who is considered to be a prisoner of war, see GC III, Art. 4, and Pictet, above note 111, Vol. III, Art. 4, pp. 44-73. The personal scope of application of GC I has to be distinguished from that of GC III: the provisions of GC I are 'essentially concerned with the dead picked up by the enemy on the battlefield, that is to say, with the mortal remains of combatants who have never for one moment been prisoners of war': Pictet, above note 47, Vol. I, Art. 17, p. 175.

126 GC IV, Arts. 129-131.

127 In terms of GC IV, Art. 4.

128 The customary rules in the ICRC Study (Henckaerts and Doswald-Beck, above note 15, Rules 112-116) simply refer to 'the dead' and thus follow - unlike the Geneva Conventions - the broadest possible ratione personae concept; the only limitation that should also apply here is that death must have resulted from an armed conflict or occupation. 
protection gaps. ${ }^{129}$ Under its Article 34(1), the obligations to respect mortal remains and gravesites and to maintain and mark gravesites apply to all persons who have died for reasons related to occupation, ${ }^{130}$ persons who have died in detention resulting from occupation or hostilities, ${ }^{131}$ and persons who are not nationals of the country in which they have died as the result of hostilities, unless they receive more favourable consideration under the Geneva Conventions or any other provision of AP I. ${ }^{132}$ However, the obligations laid down in AP I do not apply to a party's own nationals. ${ }^{133}$

\section{Gravesites and other locations of mortal remains}

The Geneva Conventions oblige the parties to an international armed conflict to ensure that graves are respected, properly or suitably maintained and marked so that they may always be found/recognized. ${ }^{134}$ The identical obligations contained in AP I as well as in customary law ${ }^{135}$ are addressed to all states on whose territories gravesites exist and thus to a wider circle of states. ${ }^{136}$ These obligations do not cease with the close of hostilities, but belong to the provisions applicable at all times. $^{137}$

It is important to note that these obligations have become customary rules, since the treaty law of non-international armed conflict is mute on the issue. This is possibly due to the fact that the performance of these obligations requires a degree of territorial control which states are usually reluctant to acknowledge non-state entities as having. However, this should not per se be an obstacle to

129 Sandoz, Swinarski and Zimmermann (eds), above note 27, Introduction to Part II, Section III, p. 341, para. 1134.

130 This would also cover, for instance, all those civilians who are not protected persons or not interned at the time of their death. Commentaries suggest that a direct causal link between occupation and death has to exist and that only death 'due to the special circumstances of occupation' would be encompassed. For examples, see Sandoz, Swinarski and Zimmermann (eds), above note 27, Art. 34, paras. 1299-1300.

131 The 'detention resulting from occupation' referred to in Article 34 of AP I is a wider concept than internment of protected persons under GC IV. If, for instance, the Occupying Power arrests and prosecutes a civilian for serious acts of sabotage, the detention would not be an internment within the meaning of GC IV; thus if such a person dies, its provisions do not apply. See Bothe, Partsch and Solf, above note 28, pp. 173 and 176.

132 In this case, death has to be a result of hostilities, such as bombardments or other attacks; however, death need not be immediate as long as a causal link is present. Sandoz, Swinarski and Zimmermann (eds), above note 27, para. 1305.

133 During the drafting of the Section containing Article 34 of AP I, there was discussion on whether it should impose obligations on a state vis-à-vis its own nationals. The working group stated in its report that these provisions do 'not impose on any High Contracting Party or Party to a conflict obligations with regard to its own nationals". This clarification was later deleted by consensus, "because it was selfevident that the article did not apply to a Party's own nationals'. Ibid., Introduction to Part II, Section III, p. 342, para. 1195 .

134 GC I, Art. 17(3); GC III, Art. 120(4); GC IV, Art. 130(1).

135 Henckaerts and Doswald-Beck, above note 15, Rules 115 and 116.

136 AP I, Art. 34.

137 See text belonging to notes 179-193 below. 
a normative development in that sense - all the more as the application of AP II is likewise conditional on territorial control. ${ }^{138}$

\section{Respect for and maintenance of burial places}

Various provisions stipulate that graves must be respected. ${ }^{139}$ The wording 'to ensure respect' indicates a positive obligation, hence active measures of protection are required. In many cases, a Graves Registration Service is mandated with ensuring respect for burial places by preventing violation of graves and sacrilege of all kinds. ${ }^{140}$ While the obligation to respect gravesites aims at preventing graves from being vandalized and the peace of the dead being disturbed, the obligation to maintain gravesites points towards activities to keep and conserve locations where persons are buried. Considering that such maintenance entails financial expenditure and that relations between the deceased's home country and the state where the graves are located are often tense, this obligation regularly gives rise to disputes. In Norway, for instance, a public debate took place in 2008 on whether the state today incurs obligations under IHL vis-à-vis combatants deceased in the Second World War and their gravesites situated on Norwegian territory. The Ministry of Culture and Church Affairs took the stance that the work carried out by the Norwegian Official Graves Registration Service, which is, inter alia, responsible for the administration of all war graves in Norway, would not be based on any international law. ${ }^{141}$

\section{Marking of gravesites}

The obligation to mark gravesites and other locations where mortal remains are situated ${ }^{142}$ is intrinsically linked to two other obligations. On the one hand, it is a concrete aspect of the broader obligation to maintain war graves. On the other hand, it is a prerequisite to guarantee access to burial places. The bearers of that obligation are free to mark the graves in the manner they see fit, as long as it is done 'in such a way that they can always be recognized' ${ }^{143}$ and 'that they may always be found' ${ }^{144}$ Most commonly, plates displaying the surname, first name and date of birth of the deceased person are affixed to the graves. ${ }^{145}$ In Norway, it was particularly the removal of name plates of war graves that caused concern, since without this information the dead become unaccounted for. ${ }^{146}$

138 AP I, Art. 1(1).

139 GC I, Art. 17(3); GC III, Art. 120(4); GC IV, Art. 130(1); AP I, Art. 34(1).

140 Pictet, above note 47, Vol. I, Art. 17, pp. 179-180. See also the section on 'Creation of a Graves Registration Service', text accompanying notes 174-178 below.

141 Norwegian Parliament, above note 4.

142 GC I, Art. 17(3); GC III, Art. 120(4); GC IV, Art. 130(1); AP I, Art. 34(1).

143 GC IV, Art. 130.

144 GC I, Art. 17(3).

145 Pictet, above note 47, Vol. I, Art. 17, p. 180.

146 Norwegian Parliament, above note 4. 


\section{Access to places containing mortal remains}

Agreements should not only be concluded to protect and maintain gravesites but also to facilitate access by relatives or representatives of Grave Registration Services. ${ }^{147}$ The wording 'facilitate access' is nebulous, but it could encompass allowing these persons to enter the territory and granting them a visa. In addition, they should be given the necessary information on the location of the gravesites. To ensure accessibility, the parties to the agreement are required to 'regulate the practical arrangements for such access'. ${ }^{148}$

\section{Recording and exchange of information on gravesites}

The Geneva Conventions require the warring parties and states on whose territories graves are located to record not only information on the dead and the circumstances of their death, but also on their burial places. Lists showing the exact location and markings of graves together with particulars of the dead interred therein must consequently be established. Provision is also made for when, by whom, and through which channels this information must be exchanged. ${ }^{149}$

\section{Duration of obligations regarding gravesites}

While the obligation applies ratione temporis at all times, it is less clear for how long states are obliged to maintain gravesites. ${ }^{150}$ Article 34 of AP I neither specifies how long the obligation lasts nor does it provide clear guidance on how to fulfil it. Rather, it provides a procedural answer on how to deal with war graves, stipulating that as soon as circumstances and the relations between the adverse parties permit, the High Contracting Parties in whose territory graves are situated shall conclude agreements in order to protect and maintain gravesites permanently. ${ }^{151}$ It is in these agreements that questions pertaining to the maintenance of burial places would then be comprehensively regulated. ${ }^{152}$

An obligation to conclude agreements on maintenance and access to gravesites is absent in the domain of non-international armed conflicts. This might be partly due to the state's concern that non-state entities could be accorded undue recognition or status under international law if such agreements were concluded on the basis of a treaty provision. Yet these objections could be met by emphasizing the spirit behind Common Article 3(2) of the Geneva Conventions stating that the

147 AP I, Art. 34(2).

148 Ibid.

149 GC I, Art. 17(4); GC III, Art. 120(6); GC IV, Art. 130(3).

150 The fact that the provision on the maintenance of gravesites applies at all times does not have any bearing on how long this obligation lasts. Rather, the temporal scope of application only determines whether a certain provision is applicable as such at a given moment; see text belonging to notes 179-193 below.

151 AP I, Art. 34(2).

152 See note 6 above for an examples of such an agreement. 
provision's application - and hence the conclusion of agreements - does not affect the legal status of the parties to the conflict. ${ }^{153}$

The drafters of AP I did not ignore the fact that - despite the obligation to conclude such agreements - negotiations and reaching a consensus might not always be possible. Article 34 therefore lays down a procedure to follow if such an agreement cannot be concluded and the home country of the deceased is not willing to arrange for the maintenance of such gravesites at its own expense. ${ }^{154}$ As a first step, the state where the graves are situated may offer to facilitate the return of the remains to the home country of the deceased. Where such an offer has not been accepted it may then, after the expiry of five years from the date of the offer and upon due notice to the home country, adopt the arrangements laid down in its own laws relating to cemeteries and graves. Domestic legislation on the subject matter is extremely diverse, but it may allow for the closure and disappearance of the gravesite. ${ }^{155}$

The Geneva Conventions do not explicitly state a time limit for the maintenance of gravesites. The wording of the provisions on the marking of graves - 'so that they may always be found'156 and 'so as to be found at any time ${ }^{157}$ - could suggest that the obligation lasts ad infinitum. The commentators on the Geneva Conventions seem to hold this view when explaining that the essential point about marking is 'that it should always be possible to find the grave of any combatant' ${ }^{158}$ However, the Commentary on AP I takes a different standpoint in that it qualifies the absence of a time limit in the Geneva Conventions as an 'obvious gap', rather than interpreting the obligation as one lasting ad infinitum and thus beyond the existence of any humanitarian interest. The commentators therefore suggest that the system foreseen in Article 34 of the Protocol should apply not only to graves covered by that provision but also to those covered by the four Geneva Conventions. ${ }^{159}$

\section{Exhumation}

The drafters of AP I, the only treaty explicitly dealing with exhumations, ${ }^{160}$ sought to strike a balance between respect for graves and the recognition of legitimate grounds for exhumation. While exhumations are as a general rule strictly prohibited, they are exceptionally permitted in two situations: first, in order to return

153 AP I, Art. 4, contains a similar provision for international armed conflicts.

154 Even in the absence of an agreement, the High Contracting Party in whose territory the graves are situated is obliged to ensure permanent maintenance if the home country of the deceased is prepared to meet the costs; Sandoz, Swinarski and Zimmermann (eds), above note 27, Art. 34, p. 376, para. 1352.

155 AP I, Art. 34(3); Sandoz, Swinarski and Zimmermann (eds), above note 27, Art. 34, pp. 376-377, paras. 1347-1353.

156 GC I, Art. 17(3).

157 GC III, Art. 120(4).

158 Pictet, above note 111, Vol. III, Art. 120, p. 566.

159 Sandoz, Swinarski and Zimmermann (eds), above note 27, Art. 34, p. 372, para. 1328.

160 AP I, Art. 34(4). 
the mortal remains to the home country; ${ }^{161}$ and second, if they are justified by 'overriding public necessity'. The latter category includes, inter alia, medical reasons or criminal investigation needs. ${ }^{162}$ The fulfilment of IHL obligations pertaining to the dead and their graves also potentially meets the necessity criterion; thus the Rapporteur of the Working Group dealing with exhumation stated: 'Where adequate protection and maintenance was not otherwise possible - for instance, in the case of scattered and temporary graves made during a battle exhumation for the purpose of regrouping graves in one location would be a matter of public necessity. ${ }^{163}$

The restrictions on exhumation as contained in Article 34(4) of Protocol I are addressed to the High Contracting Parties on whose territory graves are situated. As stated in the interpretative declaration of one delegation during the Diplomatic Conference, the provision should not, however, limit the work of Grave Registration Services: 'Paragraph 4 of the article in no way prevents the exhumation of the remains in temporary graves at the end of an armed conflict by or on behalf of a Graves Registration Service for the purpose of providing permanent gravesites, as was done after the last two European conflicts'. ${ }^{164}$

Since the drafting of that exhumation provision in the late 1970s, implementation of the obligation to prosecute serious violations of IHL has gained momentum. The establishment of numerous fact-finding commissions and international criminal tribunals at the turn of this century created a growing demand for forensic evidence, and exhumation justified by investigative necessity was thus no longer a theoretical concept. However, practice has shown that the needs of the victim's families can easily clash with the interests of investigative or prosecuting bodies. A conflict of interest can manifest itself in two ways. On the one hand, relatives might disapprove of exhumations, given that the dead and their graves should be respected and not disturbed. On the other hand, the extent of exhumations and the degree of identification might not go far enough for relatives who have an interest in recovering the mortal remains of their loved ones. International criminal tribunals often lack the resources or political will to undertake forensic investigations aimed at identifying all the dead, and confine themselves to the evidence needed to prove specific allegations. Furthermore, the 'personal identification' of the dead might not be their prime concern. For a genocide charge, for instance, the 'categorical identification' of the dead - such as the victim's ethnicity, religion or race - might suffice to establish that the perpetrator acted with intent to destroy a particular group. ${ }^{165}$ With the growing number of forensic investigations

161 AP I, Art. 34(4)(a). This could be a return of the remains to the home country, either pursuant to an agreement under AP I, Art. 34(2)(c) or, in the absence of an agreement, in one of the two situations provided for in AP I, Art. 34(3).

162 Sandoz, Swinarski and Zimmermann (eds), above note 27, Art. 34, p. 377, paras. 1355-1357.

163 Ibid., Art. 34, p. 378, para. 1359.

164 Ibid., Art. 34, p. 378, para. 1361.

165 Eric Stover and Rachel Shigekane, 'The missing in the aftermath of war: When do the needs of victims' families and international war crimes tribunals clash?', International Review of the Red Cross, Vol. 84, No. 848, December 2002, pp. 845-847. 
conducted, the need to develop and adhere to ethical and scientific standards for the exhumation and post-mortem examination of remains, which bring the interests of families and justice into the equation, has become apparent. ${ }^{166}$

\section{Bearers of the obligations regarding gravesites}

The provisions on gravesites contained in the Geneva Conventions are addressed to the 'Parties to the conflict' ${ }^{167}$ or to the 'detaining authorities' or 'Detaining Power,' respectively. ${ }^{168}$ Thus states that are not or were not a party to the conflict or a detaining power but on whose territory war graves are situated - such as the graves of German soldiers who fell in World War I and are interred in the St. Georges cemetery in Geneva, Switzerland ${ }^{169}$ - do not bear the obligations towards the dead contained in the Geneva Conventions. However, Article 34 of AP I considerably enlarges the circle of addressees: its obligations are addressed to the 'High Contracting Parties in whose territories graves and [...] other locations of the remains of persons [...] are situated'. Hence it is not necessary for the state concerned to be or have been a party to the conflict or a detaining power. ${ }^{170}$ This broader ratione personae concept is in line with the aim pursued by Article 34 of Protocol I, namely to bridge the protection gaps left by the Geneva Conventions regime. $^{171}$

There are constellations in which a party to conflict is not a High Contracting Party to Protocol I but is nonetheless bound by its provisions through the mechanisms foreseen in its Articles 96(2) and 96(3). ${ }^{172}$ Considering that many obligations with regard to the dead become especially relevant after the end of hostilities, these undertakings to be bound by Protocol I should be read broadly, i.e. as encompassing all situations and effects resulting from a specific conflict,

166 See e.g. the recommendations formulated in ICRC, Operational Best Practices, above note 44, p. 9; ICRC Report: The Missing and Their Families, Recommendation No. 23, pp. 31-32, available at: http:// www.icrc.org/Web/eng/siteeng0.nsf/htmlall/5JAHR8/\$File/ICRC_TheMissing_012003_EN_10.pdf (last visited 21 May 2009).

167 See e.g. GC I, Art. 17, and GC II, Art. 20.

168 See e.g. GC III, Art. 120, and GC IV, Art. 130. It should be noted that neutral countries can also be detaining powers; thus Soviet soldiers captured in 1982 by opposition movements in Afghanistan were interned in Switzerland. See Marco Sassòli, 'Internment', in Rüdiger Wolfrum (ed.), The Max Planck Encyclopedia of Public International Law, Oxford University Press, 2008, online edition available at: www.mpepil.com (last visited 30 January 2009).

169 See Volksbund Deutsche Kriegsgräberfürsorge e.V. (German Graves Registration Service) at: http:// www.volksbund.de/kgs/land.asp?kga=\&land=99078 (last visited 20 May 2009).

170 Henckaerts and Doswald-Beck, above note 15, Rules 112-114 and 116 are addressed only to the 'parties to the conflict'; whereas Rule 115 ('The dead must be disposed of in a respectful manner and their graves respected and properly maintained.') is not - it could therefore be held to apply to all states on whose territory graves are situated.

171 Sandoz, Swinarski and Zimmermann (eds), above note 27, Introduction to Part II, Section III, p. 341, para. 1134.

172 The authority representing the people of Nagorno-Karabakh, for instance, undertook to apply the Geneva Conventions and Additional Protocol I in relation to the armed conflict with Azerbaijan. 
otherwise equality in terms of obligations between High Contracting Parties and parties to conflict accepting and applying the Protocol would be impaired. ${ }^{173}$

\section{Creation of a Graves Registration Service}

The Geneva Conventions entrust various obligations pertaining to the dead and their graves to so-called 'Official Graves Registration Services'. ${ }^{174}$ In addition, AP I mentions them as endowed with certain privileges. ${ }^{175}$ Graves Registration Services are assigned functions both within the actual theatre of war (e.g. identification of the dead) and beyond the end of hostilities (e.g. maintenance of war cemeteries). Because of the importance of those functions, it is mandatory to establish Graves Registration Services as soon as hostilities break out. ${ }^{176}$ However, the respective IHL treaties do not specify how these services must be organized in practice and leave this to the respective state's discretion. Their activities can be carried out by government agencies: in France and Italy, for example, special ministerial departments were created; in the United States, Congress in 1923 established the American Battle Monuments Commission, which is an agency of the Executive Branch of the Federal Government. ${ }^{177}$ However, it is also possible to entrust these tasks to a private body. Germany opted for this solution and the Volksbund Deutsche Kriegsgräberfürsorge e.V. was mandated with, inter alia, the maintenance of war cemeteries. ${ }^{178}$

\section{Provisions on the dead and their gravesites: applicable at all times?}

Practice has shown that it is often disputed when and under which circumstances IHL norms on the dead and their gravesites are applicable. States are especially reluctant to accept the idea that the obligations - for instance, to identify deceased combatants - not only apply during an armed conflict, but may persist in times of peace. ${ }^{179}$ Generally, the temporal scope of application of international

173 This interpretation seems to be supported by the text in the ICRC Commentary on AP I, Art. 32, stating that the right of families to know the fate of their relatives encompasses giving the families an opportunity to remember their dead in the place where their remains lie, providing access to the gravesites and marking them (i.e. obligations pertaining to the dead that are also relevant after the conflict has ended). The Commentary continues by explaining that the 'Parties to the conflict' and the 'High Contracting Parties' are mentioned separately because some parties to the conflict may not be Contracting Parties and yet be bound by the Protocol through Article 96(2) and (3) of Protocol I: Sandoz, Swinarski and Zimmermann (eds), above note 27, p. 343, para. 1196; p. 344, para. 1206; p. 346, para. 1216.

174 See e.g. GC I, Art. 17(3); GC III, Art. 120(6).

175 AP I, Art. 34(2)(a) states that agreements should be concluded in order to facilitate access to the gravesites by representatives of Official Graves Registration Services.

176 See e.g. wording of GC I, Art. 17(3); Pictet, above note 47, Art. 17, p. 181.

177 For a description of its mandate and activities see: http://www.abmc.gov/commission/index.php (last visited 20 May 2009).

178 Michael Bothe, 'War graves', in Rudolf Bernhardt (ed), Encyclopedia of International Public Law, Vol. 2, North-Holland Elsevier, Amsterdam, 1995, p. 1374.

179 This was the case in Norway in 2008: see text belonging to notes 4 and 141. 
humanitarian $\operatorname{law}^{180}$ is identical to the material one ${ }^{181}$ (i.e. from the beginning of an armed conflict or occupation and until the close of military operations, the termination of occupation, or in either case until protected persons are released or re-established). ${ }^{182}$ However, the introductory sentence of Article 3 of AP I reads '[w]ithout prejudice to the provisions which are applicable at all times...'. Hence some IHL provisions not only apply during an armed conflict or a situation of occupation, but also in peacetime. ${ }^{183}$

The ICRC Commentary sheds some light on the question of which provisions are meant to apply at all times ${ }^{184}$ and divides them into various categories: final provisions; provisions which apply ${ }^{185}$ or may apply ${ }^{186}$ as soon as Protocol I enters into force; those giving grounds for taking preparatory measures; ${ }^{187}$ and provisions whose application in relation to a conflict may continue beyond the termination of that conflict. In this last category are listed, inter alia, the provisions on missing and dead persons (AP I, Arts. 33 and 34), reunion of dispersed families (AP I, Art. 74), repression of breaches of Protocol I (AP I, Art. 85) and mutual assistance in criminal matters (AP I, Art. 88). ${ }^{188}$ These latter provisions have a common feature in that they regulate phenomena which originate in or result from an armed conflict or occupation, but whose effects extend beyond the end of those situations. It follows that the rules regulating or remedying these effects must be applicable beyond the end of the armed conflict or occupation.

Common Article 2 of the Geneva Conventions also refers to 'provisions which shall be implemented in peacetime'. Both the travaux préparatoires and the ICRC Commentary are silent as to which provisions these are. However, by consulting the records of the Diplomatic Conference on Protocol I, thus by putting the cart before the horse, it can be seen that the rationale behind the temporal scope of application of provisions of the said Protocol and the Geneva Conventions is the same. ${ }^{189}$ It therefore seems justified to apply the same kind of provisions at all times.

180 The temporal scope of application of the Geneva Conventions is laid down in GC I, Arts. 2 and 5; GC II, Art. 2; GC III, Arts. 2 and 5; and GC IV, Arts. 2 and 6. However, the wording of AP I, Art. 3(a) - 'the Conventions and this Protocol shall apply...' - indicates that the temporal scope of application rule of Protocol I also governs the Geneva Conventions and replaces their relevant provisions.

181 AP I, Art. 1(3) and (4), referring to Article 2 common to GC I-IV.

182 For the beginning of application see AP I, Art. 3(a), referring to AP I, Art. 1, which in turn refers to Article 2 common to GC I-IV; for the end of application see AP I, Art. 3(b).

183 Sandoz, Swinarski and Zimmermann (eds), above note 27, Art. 3, p. 66, paras. 145-146.

184 The ICRC draft of Protocol I with commentary provides a list of provisions applicable at all times: Draft Additional Protocols to the Geneva Conventions of August 12, 1949: Commentary, ICRC, Geneva, October 1973, p. 10. Since draft Protocol I did not contain any provisions on the missing or the dead (they were only introduced at a later stage of the drafting process), the gravesite provisions could not possibly be included in this list.

185 e.g. AP I, Art. 83, on dissemination.

186 e.g. AP I, Art. 7, on meetings.

187 e.g. AP I, Art. 58, on precautions against the effects of attacks.

188 Sandoz, Swinarski and Zimmermann (eds), above note 27, Art. 3, p. 66, para. 149.

189 The ICRC draft provision on AP I's temporal scope of application differed from the text retained in Article 3, and was only later changed into the present wording. It read 'In addition to the provisions applicable in peace time, the present Protocol shall apply...' Draft Additional Protocols to the Geneva Conventions of August 12, 1949, Commentary, ICRC, Geneva, October 1973, p. 9. With regard to this 
A further point to be noted is that the gravesite provision of AP I, ${ }^{190}$ which is applicable at all times, is linked to GC IV, as it states that: 'gravesites [...] shall be respected, maintained and marked as provided for in Article 130 of the Fourth Convention'. Given this technical linkage between the two provisions, but also the fact that they contain the same core ideas, not only Article 34 of AP I on mortal remains but also the provisions of the Geneva Conventions on the dead belong to the category of provisions that are applicable at all times.

The situation in non-international armed conflicts, however, appears to be different. Since Common Article 3 applies only to situations reaching the threshold of a non-international armed conflict, and not to internal disturbances or tensions, ${ }^{191}$ it can be held that it is a fortiori not applicable in times of peace. The same can be said of Article 8 of AP II, as the existence of an armed conflict meeting the criteria of Article 1(1) thereof is required for the Protocol to apply; there is moreover the clear stipulation that the Protocol 'shall not apply to situations of internal disturbances and tensions'. ${ }^{192}$ Nor does it contain a clause allowing for provisions that are applicable at all times. So Article 8 of AP II does not seem to apply beyond the termination of an armed conflict either. ${ }^{193}$

\section{The applicable body of law: past or present IHL rules?}

\section{The issue: persisting facts - evolving legal rules}

Legal questions with regard to mortal remains or war cemeteries arise not only when a person dies or when the gravesite is built, but often decades later. For example, many European countries now face the question of how to deal correctly with graves where people who died during the two world wars are interred. Do these gravesites have to be maintained, or can a conflicting construction project be given priority? ${ }^{194}$ Can a war memorial be removed or transferred because it is perceived by part of the population as a thorn in their side? ${ }^{195}$ Or can collective

wording, an ICRC delegate at the Conference stated that: "in using the expression "in peacetime", the ICRC had based itself on the terminology of the Geneva Conventions.' - Official Records of the Diplomatic Conference of the Reaffirmation and Development of International Humanitarian Law Applicable in Armed Conflicts, Geneva (1974-1977), ICRC, CDDH/I/SR.10, Vol. VIII, p. 74.

190 AP I, Art. 34(1).

191 ICRC, 'How is the term “armed conflict” defined in international humanitarian law?', Opinion Paper, March 2008, p. 3, available at: http://www.icrc.org/web/eng/siteeng0.nsf/htmlall/armed-conflict-article170308/\$file/Opinion-paper-armed-conflict.pdf (last visited 21 May 2009).

192 AP II, Art. 1(2).

193 Against this textual interpretation of the treaty, the teleological argument could be made that several provisions of AP II (e.g. Article 19 entitled 'Dissemination') are clearly meant to apply at all times. However, this reading is not supported by the wording of the Protocol's scope of application rules.

194 Olga Bondaruk, 'Ukraine Jews want graves building halted', Associated Press, 23 July 2008, available at: http://abcnews.go.com/International/wireStory?id=5433924 (last visited 20 May 2009).

195 'Estonia removes Soviet memorial', BBC News, 27 April 2007, available at: http://news.bbc.co.uk/2/hi/ europe/6598269.stm (last visited 20 May 2009). 
graves containing soldiers' remains be excavated to allow for individual burial? ${ }^{196}$ Given that these fact patterns comprise elements of past and present times (i.e. are of a continuing nature) and that IHL evolves over time, the question is whether these juridical facts have to be assessed in the light of past or present IHL norms. ${ }^{197}$

\section{The approach: the doctrine of intertemporal law}

The doctrine of intertemporal law provides an answer to the question of whether to apply, for example, the IHL rules which were in force at the time a gravesite was constructed, or those in force when, for instance, the financing of the maintenance of a war cemetery is disputed. Arbitrator Huber defined intertemporal law in the Island of Palmas case before the Permanent Court of Arbitration as 'the rules determining which of successive legal systems is to be applied' or as 'the question which of different legal systems prevailing at successive periods is to be applied in a particular case' ${ }^{198}$ He further stated that according to intertemporal law, 'a juridical fact must be appreciated in the light of the law contemporary with it, and not of the law as in force at the time when a dispute in regard to it arises or falls to be settled'. ${ }^{199}$ The principle of non-retroactivity is one facet of this broader rule ${ }^{200}$ and is laid down in Article 28 of the Vienna Convention on the Law of Treaties ${ }^{201}$ in the following terms: 'Unless a different intention appears from the treaty or is otherwise established, its provisions do not bind a party in relation to any act or fact which took place or any situation which ceased to exist before the date of the entry into force of the treaty with respect to that party.' Hence intertemporal law dictates that legal rules contemporaneous with the acts control their legal significance. ${ }^{202}$

\section{The solution: the law of today applies to facts of a continuing nature}

In order to apply the criterion of contemporaneity, the nature of facts relating to mortal remains and gravesites must be determined, i.e. whether these are

196 'Australian, British WWI remains to be reburied', Agence France Presse, 1 August 2008, available at: http://www.brisbanetimes.com.au/news/world/australian-british-wwi-remains-to-be-reburied/2008/08/ 01/1217097470597.html (last visited 20 May 2009).

197 During the First and Second World Wars, for instance, the four Geneva Conventions of 1949 were not yet in force and there were only fragmentary regulations for dealing with the dead and their gravesites, e.g. in the 1929 Convention for the Amelioration of the Condition of the Wounded and Sick in Armies in the Field, the 1907 Convention (X) for the Adaptation to Maritime Warfare of the Principles of the Geneva Convention, and the 1929 Convention relative to the Treatment of Prisoners of War.

198 Permanent Court of Arbitration, Island of Palmas Case (United States of America v. The Netherlands), Award of the Tribunal, 4 April 1928, p. 15, available at: http://www.pca-cpa.org/upload/files/ Island\%20of\%20Palmas\%20award\%20only\%20 + \%20TOC.pdf (last visited 20 May 2009).

199 Ibid., p. 14.

200 Frédéric Dopagne, 'Article 28 - Convention de Vienne de 1969', in Olivier Corten and Pierre Klein (eds), Commentaire article par article des Conventions de Vienne de 1969 et 1986 sur le droit des traités, Vol. 1, Bruylant, Brussels, 2006, pp. 1165 and 1174.

201 Vienna Convention on the Law of Treaties, done at Vienna on 23 May 1969, entered into force on 27 January 1980, 1155 UNTS 331.

202 Anthony D'Amato, 'International law: Intertemporal problems', in Rudolf Bernhardt (ed), Encyclopedia of International Public Law, Vol. 2, North-Holland Elsevier, Amsterdam, 1995, p. 1235. 
past/completed or present/continuing facts. While international humanitarian law as in force today can be applied to present and continuing facts, this is not the case for events of yesterday, i.e. for any act taking place or any situation that ceased to exist before a specific IHL provision entered into force.

Most situations involving mortal remains or gravesites cannot be qualified as completed or isolated acts lying in the past. Rather, they are of a continuing or even present nature. Their ongoing nature is reflected by the very core provision on the subject matter, which stipulates that gravesites have to be respected and maintained. ${ }^{203}$ Both obligations can only be fulfilled by continued activity and are suggestive of a situation persisting over time. The continuing nature of these facts is also reflected by the wording of various gravesite provisions, such as Article 17(3) of GC I stipulating that 'graves are [...] marked so that they may always be found'. Obligations ensuring that the dead are accounted for - such as the registration, forwarding, and keeping of information on the dead and their burial places ${ }^{204}-$ also do not cease at a given moment but persist over time. Other obligations can be dormant and may only materialize long after death, such as those pertaining to exhumation, identification or return of mortal remains. ${ }^{205}$ Given that the facts dealt with are of a continuing or present nature, the principle of intertemporal law, which requires contemporaneity between fact and law, dictates that the IHL in force today be applied.

\section{The appraisal: applying today's law - the least problematic approach in practice}

Application of the IHL body of law as in force today to current legal questions pertaining to human remains and war cemeteries - rather than the law as in force when the person died or the grave was constructed - also seems reasonable from a purely practical point of view. In many cases the information available on the dead or their graves is very poor and it would be difficult to establish the exact time when death occurred or the grave was built. This may be due to the fact that the person was buried in the turmoil of war, or to the low documentation standards prevailing several decades ago or in a war-torn country, or also because the information is purposely withheld, as in the case of a mass grave built to conceal traces of a crime.

Application of the law as in force at the time of death or burial would furthermore lead to a fragmented legal regime, since a fact pattern often comprises elements attributable to different points of time in the past. It is for instance not uncommon for soldiers who died in the First and Second World Wars to be buried at the same war cemetery, as at the Suresnes American Cemetery and Memorial in 
France, which now shelters the remains of US dead of both wars. ${ }^{206}$ Often graves are constructed in a provisional way during a battle and (sometimes decades) later relocated and/or transformed into a more permanent structure. For instance, four provisional burial sites in Belgium - Henri-Chapelle, Fosse, Overrepen and Neuville-en-Condroz - were later replaced by the war cemetery in Lommel, which is the largest military cemetery in Western Europe for German soldiers who died in the Second World War. ${ }^{207}$ Applying the IHL rules as in force today enables the situation to be taken into account as it has evolved with the passage of time, and with all the features it displays today. The situation is thereby governed by one and the same set of rules.

Finally, the difficulties pertain not only to the establishment of the facts but also to the determination of the law as in force several decades or a century ago. This holds especially true with regard to customary international law, and also to situations where one state succeeded another, for instance through secession, annexation or decolonization.

\section{Conclusion}

The substantive provisions of international humanitarian law on the dead and their gravesites applicable in international armed conflicts are quite comprehensive and regulate most of the issues relating to people who have died in armed conflict. Moreover, these provisions apply not only during but also after an armed conflict or occupation. Although they are comprehensive in terms of content and application at all times, there are nonetheless protection gaps in the four Geneva Conventions, resulting first and foremost from their limited personal scope of application (mostly confined to protected persons). In addition, under the Conventions only a narrowly defined category of states (i.e. parties to conflict and detaining powers) bear specific obligations pertaining to the dead. In Protocol I, the provisions on 'missing and dead persons' were designed to bridge the protection gaps left by the humanitarian law regime adopted in the aftermath of the Second World War. This treaty not only extends the circle of persons protected by IHL but also places obligations on states that have neither been a party to the conflict concerned nor a detaining power. Although Protocol I has not yet been universally ratified, its core ideas and those of the Geneva Conventions have been consolidated in customary international law and are thus applicable to every state.

With regard to non-international armed conflicts, only very few specific substantive norms on the dead and their graves exist. However, all parties to such a

206 For a description of the Suresnes American Cemetery and Memorial provided by the American Battle Monuments Commissions, see http://www.abmc.gov/cemeteries/cemeteries/su.php (last visited 20 May 2009).

207 The Volksbund Deutsche Kriegsgräberfürsorge e.V. (German Graves Registration Service) provides more information about gravesites of German war dead in Belgium and elsewhere: http://www.volksbund.de/ kgs/land.asp?land=99009 (last visited 20 May 2009). 
conflict are bound by general IHL obligations - such as the prohibition of outrages upon personal dignity, cruel and inhuman treatment, and collective punishment which also confer protection on the dead person and his or her relatives. Moreover, except for the obligation to facilitate the return of the remains and personal effects of the deceased, the customary rules as identified by the ICRC apply not only to international but also to non-international armed conflicts.

Finally, it must be stressed that while international humanitarian law is an important body of law protecting the deceased and their next of kin, it is not the only one. International human rights law - despite the absence of specific rules on the dead - contains general rules which could also be effective in protecting the human dignity of the deceased and safeguarding the rights and needs of their relatives. 